resulted in recognition that the work of librarians in special libraries and of information officers has a character of its own, and in the consequent formation of associations providing a platform for the discussion of common interests. The Association of Special Libraries and Information Services (A.S.L.I.S.) in Melbourne, Australia, is one of these, and it is to be congratulated on the launching of its journal, Information, in June 1947. This first issue contains, besides introductory matter, the first part of an article on documentary reproduction, another on patents in information, glimpses of the B. J. Ball, Ltd., library in Melbourne, and the constitution of the Association. An exchange corner for periodicals, abstracts of relevant literature, and questions and answers on the universal decimal classification are other features which will appeal to members. Although printing difficulties may make the appearance of the journal infrequent at first, it has made a good start. It should, perhaps, be mentioned that the Australian organisation A.S.L.I.S. is quite independent of the Association of Special Libraries and Information Bureaux (A.S.L.I.B.) in Great Britain, though the two are in very cordial relationship.

\section{Indians of the South-Eastern United States}

THE historical Indian tribes of the south-eastern United States are diverse in language, but they share so many important characteristics that they form a cultural province. This is illustrated by the arrangement of Mr. Swanton's massive work (Smithsonian Institution : Bur. of Amer. Ethnology, Bull. I37. Pp. xiii $+943+107$ pl. Washington, D.C. : Gov. Print. Office. 2.75 dollars), in which a brief, purely historical sketch of each individual tribe is given first, leaving the material culture to be dealt with as a whole. The book may be considered as supplementing and bringing up to date the relevant parts of the great two-volume Handbook of American Indians North of Mexico, edited by F. W. Hodge, published as Bulletin 30 of the same series in 1907 and 1910. The author regards it principally as a collection of source materials, and as such he hopes that it will be useful to future students. This hope should be fully realized, and in addition it will be a most useful book of reference. Some of the plates are not well chosen. It is difficult, for example, to see what is to be learnt from the rather distant group, in Edwardian dress, in front of a modern wooden building, labelled "Ladies Relief Society of the Church of Jesus Christ of Latter Day Saints, Catawba Reservation" (Plate 5). The space occupied by this and some others might have been better employed in illustrating objects of material culture.

\section{Bibliography of Seismology}

Vouume 13, No. 19 of the Bibliography of Seismology, published by Dr. Ernest A. Hodgson from the Dominion Observatory, Ottawa, Canada, covers items 6,047-6,142 and carries the bibliography to the end of June 1946. This valuable publication, which deals with pure and applied seismology and subjects throwing light on them, covers in this issue world books, papers and works published on the Continent of Europe during the years 1939-45, together with a small list of patents. There are fourteen items from Holland including an obituary notice of Dr. G. Van Dijk (1877-1940), L. P. G. Koning on deep focus earthquakes (items 6,094-95), F. H. van Rummelen and S. W. Visser on Dutch earthquakes, and a text-book on seismology by S. W. Visser (items $6,135,6,137-38$ ). The items from Finland, five in number, consist of four papers on isostasy and one on pure seismology, namely, Eijo Vesanen's "Ueber die typenanalytische Auswertung der Seismogramme" (Ann. Acad. Sci. Fennicce, A, 3, Geologica-Geographica, 5, pp. 244. Helsinki, 1942). Three items from France include obituary notices of Dr. Edmund Rothé and Dan Barfod La Cour and an article on French geophysics during the War. Item 6,107 contains references to a most important topical seismological question, namely, the use of the seismograph as a meteorological instrument; by means of micro. seisms tropical storm and cyclone centres at sea can be located and tracked. There is a list of the seismological items published in Nature.

\section{An Unusual Asteroid}

AN asteroid discovered in August by C. A. Wirtanen, Lick Observatory, is described in Sky and Telescope of October. Its magnitude at the time of discovery was 15 , and it is estimated that its diameter is only a few miles. Its orbit is nearly circular and lies close to that of Mars, approaching the orbit of Mars to within 6 million miles; but its least distance from the earth is about 50 million miles. Its period is nearly $2 \cdot 3$ years-the shortest period of any asteroid with the exception of Eros.

\section{Institution of Mining and Metallurgy: Officers for 1948-49}

THE following have been elected officers of the Institution of Mining and Metallurgy for the session 1948-49: President, Mr. Sydney E. Taylor; Hon. Treasurer, Mr. Robert Annan; Vice-Presidents, Mr. G. Keith Allen, Mr. Donald Gill, Mr. V. Harbord, Colonel L. C. Hill, Sir Arthur Smout and Brig. R. S. G. Stokes. Mr. S. E. Taylor, the new president, was educated at Cambridge, where he read engineering science. He joined the technical staff of Messrs. John Taylor and Sons, managers and consulting engineers to mines in many countries, in October 1922, and became senior partner in 1941. In 1924 he visited Brazil, and since 1923 has paid numerous visits to India in connexion with the management of the mines on the Kolar Gold Field in Mysore State, and the re-opening of the Hutti gold mine in Hyderabad State.

\section{Announcements}

THE Royal Society is compiling a list of British scientific societies, together with the names of their officers, etc. As it is desired to make this as comprehensive as possible, it would be appreciated if any secretaries of such societies, who have not yet received a questionnaire from the Royal Society, would inform the Assistant Secretary, Royal Society, Burlington House, London, W.l.

Trintry Contege, Cambridge, offers research studentships and Dominion and Colonial exhibitions every year, and elections will take place in July 1948. Research studentships are open to graduates of universities other than Cambridge who are not more than twenty-six years of age. The exhibitions are open to undergraduates as well as those wishing to undertake research. Applications, to be sent through the head of the candidate's university, must reach the Senior Tutor, Trinity College, Cambridge, not later than May 1, 1948. 